\title{
Sustainability Practices and Financial Performance: Evidence from Islamic Banking in Indonesia
}

\author{
Angga Septian Prayoga ${ }^{1}$, Dodik Siswantoro ${ }^{2}$ \\ \{angga.septian81@ui.ac.id¹, dodik.siswantoro@ui.ac.id² \\ Department of Accounting, Faculty of Economics and Business, Universitas Indonesia, Depok, Jawa Barat, \\ 16424 , Indonesia ${ }^{12}$
}

\begin{abstract}
In Islamic banking, sustainability practices and its reporting are very low, due to limited literature and frameworks for measuring sustainability. This study measures the level of sustainability practices (economic, environmental, and social) based on GRI (Global Reporting Initiative) items that are transformed with Maqasid Al-Sharia theory and investigate its relation to financial performance. Based on weighted content analysis methods in annual and sustainability reports related to 11 Islamic banks in Indonesia for $2014-2018$. The results indicate the average number of sustainability practices at Islamic banking in Indonesia is very low, only $23.33 \%$ and there has been an increasing sustainability trend from 2014 until 2018 but these practices have no relation to financial performance. These results support an urgent need for appropriate sustainability guidelines for Islamic banking, especially in Indonesia.
\end{abstract}

Keywords: Sustainability, Financial Performance, Islamic Banking

\section{Introduction}

The excessive and irresponsible use of natural resources, especially by companies, has resulted in various economic, environmental, and social problems such as poverty, depletion of natural resources, global warming, accumulation of toxic waste and chemicals, and increasing human rights violations. As a form of companies' concern about the problems, the need for sustainability practices and reporting has drawn important attention in the last two decades [29]. Disclosure of non-financial performances such as corporate social responsibility (CSR) and sustainability reports is considered a firm commitment of the organizations to the application of sustainability practices by many stakeholders [44]. This is confirmed by the adoption of international guidelines on sustainability reporting such as the Global Reporting Initiative (GRI), which are based on the KPMG survey (2017) more than $93 \%$ of the 250 largest corporations in the world have published the report.

Unlike conventional banks, Islamic banks refer to a system that is guided by Islamic economic principles which are based on the Al-Qur'an and Hadith. Islamic banking is formed from Islamic ontological and epistemological sources the concepts of social virtue, good governance, environmental concern, and ethical behavior of individuals and organizations [3] [4] [5]. The practice of social responsibility is a consequence of Islamic ethics because Islam as a religion shows a proactive stakeholder paradigm through the establishment of company moral obligations towards society [42]. Besides, Islamic banks have two main models in their banking 
transactions related to sustainability (the Chapra and Ismail models), namely the institutional and welfarist approaches. The institutional approach emphasizes the maximization of the value of bank owners (shareholders and account holders) while the welfarist approach is the realization of Maqasid Al-Sharia by improving people's welfare [2] [32] [35] [41]. Therefore, it can be said that sustainability is related and relevant to the concept of Islamic banking.

However, in the case of the Islamic banking industry, the rate of sustainability practices and reporting in this world is very low. In research by [34], it was found that the rate of sustainability of Islamic banks' disclosure in Indonesia and Malaysia was only 26 percent. [38] found that in the United Arab Emirates the disclosure of the sustainability of Islamic banks was very low compared to conventional banks. [31] researched 91 Islamic banks in 13 countries and found that Islamic banks in those countries paid less attention to sustainability practices and disclosures. Research by [12] reported the inefficient practices of sustainability and disclosures in 14 Islamic banks from 14 different countries. Further, [20] examined the sustainability practices and reporting of Islamic banks from 7 Muslim countries and the results indicate the sustainability practices and reporting were not the main concerns for Islamic banks in those countries.

According to [25], the low rate of sustainability practices and reporting in Islamic banking is likely caused by limited literature on sustainability in Islamic banking, and the frameworks to measure the practices are inadequate. For that reason, there is an urgent need to propose a framework for measuring sustainability that matches the Islamic banking concept and to evaluate its impact on financial performance [24].

Based on the background, gaps, and suggestions from the previous research, this topic is appealing to be reexamined, how the relation of sustainability practices toward the financial performance in Islamic banking is? As far as we know, this study is the first study that measures the practice of sustainability in Islamic banking for 2014 - 2018 based on the GRI that are transformed with Maqasid Al-Sharia theory refers to [25]. Indonesia is chosen as the sample because Indonesia is a country with the largest Muslim population in the world, with around $87 \%$ of the population embracing Islam [51] and included in ten countries with sharia financial markets that are growing rapidly in the world based on the indicators quantitative development, knowledge, governance, corporate social responsibility, and awareness of Islamic finance [22].

\section{Literature Review and Hypothesis}

\subsection{Stakeholder Theory}

A stakeholder theory explains to which party the company must take responsibility. The company must maintain its relationship with stakeholders, especially those who influence the company's operational activities. A stakeholder theory identifies the existence of different actors in addition to shareholders who also have a great deal of interest in the company's decisions and therefore want to gain information about the company's behavior. This theory that companies are not only responsible to shareholders but also to every individual or group that influences or may be influenced by the actions of the organization [17] and a strategy that can be carried out by companies to maintain a good relationship with stakeholders is by conducting sustainability practices.

\subsection{Sustainability Practices According to Maqasid Al-Sharia}

In Arabic, maqasid means goal, purpose, or intention, while sharia is Islamic law. Maqasid Al-Sharia can be defined as the goal of Islamic law and in general, according to [21], Maqasid Al- 
Sharia is a public interest to achieve justice and provide benefits to humans. [45] explained that the Maqasid Al-Sharia was first studied in 1058 - 1111 by Ulama Al Ghazali that Maqasid AlSharia aimed to protect deen (faith), nafs (self or life), aql (intellect), nasl (posterity), and maal (wealth) to improve the social and economic life of mankind. In 1388, Al Syatibi developed the study of Maqasid Al-Sharia by classifying it into three levels of maslahah, namely daruriyat (essentials), hajiyaat (complimentary), and tahsiniyat (embellishments).

The term sustainability is first defined in the Brundtland Report [11]. This report defined the meaning of sustainability as a process of economic growth, environmental protection, and social equality. Sustainability in business is referred to as a process by which companies manage economic risk, environmental risk, social business risk, and their obligations and opportunities. There are three main aspects of sustainability, i.e. economic, environmental, and social. Islamic banks with an application of Islamic principles in their business should be advanced in practicing sustainability concepts through the implementation of sustainability practices. Islamic values that become the basis of Sharia banking business activities such as the prohibition of damaging, the prohibition of doing wrong to others, the suggestion of mutual giving, and so on, support and is in line with the sustainability concept. One of the principles is in accordance with Al-Qur'an Surah Al-A'raf verse 56: "And cause not corruption upon the earth after its being tilled". Therefore, based on this explanation, it can be concluded that the sustainability concept is in accordance with Maqasid Al-Sharia concept which aims to provide human welfare.

Sustainability practices that were transformed based on Maqasid Al-Sharia in research by [25] included Shariah screening during the investment, Allocation of profit based on Shariah principles, Zakat payment, Qardh-e-Hassan / Benevolent funds, Charity - Sadaqah - Waqaf, Disclosure of earnings prohibited by Shariah, Compliance with Islamic laws for the environment, Islamic training and education to the staff, Sponsoring pilgrimage, Scholarships, and Products and services labeling (approved by the Shariah committee).

\subsection{Hypothesis Development}

Banks can play an important role in economic development [8] since they decide how to allocate financial resources to different sectors. Involvement of banks in social and environmental responsibilities must benefit the banks themselves and also promote the application of sustainability practices to potential borrowers, thereby providing a positive impact on sustainable growth [14]. Nowadays, bank clients have more concern about environmental, social, and governance issues [41] [52] which indicates that sustainability practices also have an important role in banking profitability.

A reason why Islamic banks have better disclosures than conventional banks is the existence of an Islamic perspective related to ethical matters, where Islam's role becomes an important factor behind the better disclosure of sustainability. Islamic banks are also in the leading position in terms of generating profits. The previous studies show that profits, in the long-term, have a positive effect on social and environmental disclosure [15] [19] [23]. Further, several Islamic banks claim to be pioneers in carrying out and disclosing social welfare activities [46].

Research on Islamic banking conducted by [46] empirically explored the rate of sustainability disclosure in annual reports and websites of 29 banks listed on the Bangladesh 
Stock Exchange by distinguishing between Islamic banks and conventional banks. In their research, they measured economic, environmental, and social disclosure and found that Islamic banks disclosed more information about sustainability in annual reports and websites than conventional banks. [25] examined the relationship between sustainability practices and financial performance based on Islamic perspectives in Malaysia for a decade 2008 - 2017 and the results showed that sustainability practices have a significant positive relationship on Islamic bank financial performance. Based on the arguments and results from the previous studies, the hypothesis is:

$H_{1}$ : Sustainability practices are positively related to Islamic banking's financial performance.

\section{Method}

The population of this study is all Sharia Commercial Banks in Indonesia. The sample collection uses purposive sampling method with the following criteria (a). Sharia Commercial Bank issued complete Annual Reports or Sustainability Reports successively during the period 2014 - 2018 (b). Bank has been operating for a minimum of 1 year. Researchers choose the years 2014 - 2018 with a consideration that the disclosures to be analyzed can illustrate the latest data on the practices of sharia banking sustainability in Indonesia. Further, to test the hypothesis, we used the regression method using software Stata 14.2, with a research model from [25] that had been modified as follows:

$$
R O A_{i t}=\alpha+\beta_{1} S U S P i t+\beta_{2} S I Z E_{i t}+\beta_{3} A G E_{i t}+\beta_{4} C A R_{i t}+\beta_{5} L E V_{i t}+\varepsilon_{i t} \quad \text { (1) }
$$

Sustainability practices are measured using a proxy developed by [25]. The research has transformed the framework of the Global Reporting Initiative (2016) with the Maqasid AlSharia theory and the parameters of Islamic item measurement based on the previous research so that the new framework is more relevant in measuring sustainability from the perspective of Islamic banking. The total number of sustainability practice items are 65 disclosures divided into four aspects, 7 items of general standards disclosure, 10 items of economic sustainability, 12 items of environmental sustainability, and 36 items of social sustainability. The parameter used to measure individual items is weighted content analysis methods are Fully-Reported $=(2)$, Partially-Reported $=(1)$, No-Reporting $=(0)$. In the content analysis, the researchers choose two persons who are used to do sustainability scoring on companies based on GRI as scorers, so that the result of the study is expected to have good validity and reliability.

The banking performances were measured with Return on Assets (ROA), net income divided by total assets. ROA is considered a basic measure of bank profitability including Islamic banking. This proxy can measure how well a bank manager is performing, show how well bank assets are used to generate profits, and is the most popular and most used proxy in the previous studies and the most recent research [7] [39] [47] [49].

Control variables that are determinants of ROA consist of firm-specific, such as Bank Size, Bank Age, Capital Adequacy Ratio, and Leverage Ratio. The variable size is used in most research as a determinant of bank profitability such as research by [13] [26] [30]. The older banks are generally considered to be more profitable and bigger [26]. To avoid criticisms from interest groups, older banks will adopt more sustainable measures and practices for the environment and society in general. The high Capital Adequacy Ratio (CAR) shows that banks have sufficient funds available and require fewer external funds to benefit high profitability and 
vice versa [27]. Finally, Leverage Ratio (LEV) is a ratio to see the companies' ability to pay their debts, since there is a risk that the company cannot fulfill these payments. The research that uses leverage as a control variable that influences performance is research by [9] [36] [37].

\section{Results}

\subsection{Descriptive Statistics}

This study uses balanced panel data at 11 Sharia Commercial Banks in Indonesia during the period 2014 - 2018 that have met the research criteria. Table 1 shows descriptive statistics with a total final sample of 55 observations. In the table, we can see the General Standard Disclosure, Economic, Environment, Social, and Total Sustainability. The average of sustainability disclosure in Islamic banks in Indonesia is 30.33 with a deviation of 14.55, the lowest score is 14 while the highest score is 70. Meanwhile, Table 2 shows the average percentage of sustainability practices during 2014 - 2018 which is very low, only $23.33 \%$. However, this trend has increased over the last 5 years with an average increase of $50.19 \%$.

The average financial performance that is proxied in ROA of $-0.5172 \%$ shows the inefficiency of the rate of assets repayments in Islamic banks, while the deviation is 3,936\%. the lowest ROA of $-20.13 \%$ is owned by Maybank Syariah in 2015 and the highest ROA is owned by Maybank Syariah 5.5\% in 2017.

The average size of banking or banking assets amounted to Rp 21,180 billion, with the lowest total assets in Maybank Syariah Rp 661,912 million in 2018 and the highest in Bank Syariah Mandiri Rp 98,341 billion in 2018. In the meantime, other control variables such as Bank Age, in 2015 were the youngest banks to operate, which is 4 years old. Victoria Syariah, BJB Syariah, Mega Syariah, Maybank Syariah, BCA Syariah, and BNI Syariah and the oldest bank that is 23 years old is Bank Muamalat. The average Capital Adequacy Ratio is $24.10 \%$ with a standard deviation of $22.43 \%$, the lowest value is $11.51 \%$ at Bank Panin Syariah in 2017, while the highest value is Maybank Syariah $163.07 \%$ in 2018. Lastly, the Leverage or average risk ratio is $22.43 \%$, with a standard deviation of $22.00 \%$. The lowest value is at Bank Victoria Syariah in 2014 amounted to $5.75 \%$ and the highest is Bukopin Syariah in 2014 amounted to $90.24 \%$.

Table 1. Descriptive Statistics

\begin{tabular}{llllll}
\hline \multicolumn{1}{c}{ Variable } & $N$ & Min & Max & Mean & Std. Dev. \\
\hline General Standard Disclosure & 55 & 7 & 14 & 9.181818 & 2.632355 \\
Economic Sustainability & 55 & 2 & 13 & 6.363636 & 3.15268 \\
Environment Sustainability & 55 & 0 & 15 & 1.509091 & 3.463421 \\
Social Sustainability & 55 & 4 & 28 & 13.27273 & 7.009133 \\
Total Sustainability & 55 & 14 & 70 & 30.32727 & 14.55266 \\
Return on Assets & 55 & -0.2013 & 0.055 & -0.0051727 & 0.0393685 \\
Bank Size & 55 & 27.2184 & 32.21946 & 29.92535 & 1.301265 \\
Bank Age & 55 & 4 & 27 & 9.181818 & 6.098242 \\
Capital Adequency Ratio & 55 & 0.1151 & 1.6307 & 0.2410382 & 0.2232165 \\
Leverage Ratio & 55 & 0.0575381 & 0.9024065 & 0.224383 & 0.2200564 \\
\hline
\end{tabular}


Table 2. Sustainability scores of Islamic banking in Indonesia

\begin{tabular}{|l|c|c|c|c|c|c|c|c|}
\hline \multirow{2}{*}{ Bank } & $\begin{array}{c}\text { Average General } \\
\text { Disclosure Score } \\
(2014-2018)\end{array}$ & $\begin{array}{c}\text { Average } \\
\text { Economic Score } \\
(2014-2018)\end{array}$ & $\begin{array}{c}\text { Average } \\
\text { Environmental } \\
\text { Score (2014- } \\
2018)\end{array}$ & $\begin{array}{c}\text { Average } \\
\text { Social Score } \\
(2014-2018)\end{array}$ & $\begin{array}{c}\text { Average } \\
\text { Sustainability } \\
\text { Score }(2014- \\
2018)\end{array}$ & \multicolumn{2}{|c|}{$\begin{array}{c}5 \text { Year Trend in } \\
\text { Sustainability Score }\end{array}$} \\
\cline { 5 - 9 } & & & & & 2014 & 2018 & Increase \\
\hline Muamalat & $74.29 \%$ & $50.00 \%$ & $16.67 \%$ & $28.61 \%$ & $34.62 \%$ & 37 & 57 & $54.05 \%$ \\
\hline BNI Syariah & $95.71 \%$ & $57.00 \%$ & $35.00 \%$ & $33.33 \%$ & $44.00 \%$ & 39 & 70 & $79.49 \%$ \\
\hline BCA Syariah & $50.00 \%$ & $15.00 \%$ & $0.00 \%$ & $6.94 \%$ & $11.54 \%$ & 15 & 15 & $0.00 \%$ \\
\hline BRI Syariah & $82.86 \%$ & $35.00 \%$ & $5.00 \%$ & $20.83 \%$ & $26.77 \%$ & 24 & 42 & $75.00 \%$ \\
\hline BSM & $82.86 \%$ & $42.00 \%$ & $0.00 \%$ & $25.83 \%$ & $29.69 \%$ & 26 & 47 & $80.77 \%$ \\
\hline Maybank Syariah & $50.00 \%$ & $15.00 \%$ & $0.00 \%$ & $9.72 \%$ & $13.08 \%$ & 17 & 17 & $0.00 \%$ \\
\hline Mega Syariah & $57.14 \%$ & $27.00 \%$ & $5.00 \%$ & $23.61 \%$ & $24.31 \%$ & 22 & 38 & $72.73 \%$ \\
\hline Panin Syariah & $57.14 \%$ & $41.00 \%$ & $0.00 \%$ & $19.72 \%$ & $23.38 \%$ & 28 & 32 & $14.29 \%$ \\
\hline Bukopin Syariah & $57.14 \%$ & $31.00 \%$ & $7.50 \%$ & $14.72 \%$ & $20.46 \%$ & 18 & 32 & $77.78 \%$ \\
\hline BJB Syariah & $57.14 \%$ & $27.00 \%$ & $0.00 \%$ & $13.89 \%$ & $18.00 \%$ & 19 & 25 & $31.58 \%$ \\
\hline Victoria Syariah & $57.14 \%$ & $10.00 \%$ & $0.00 \%$ & $5.56 \%$ & $10.77 \%$ & 14 & 14 & $0.00 \%$ \\
\hline $\begin{array}{c}\text { Average for the } \\
\text { Overall Dimension }\end{array}$ & $65.58 \%$ & $31.82 \%$ & $6.29 \%$ & $18.43 \%$ & $23.33 \%$ & $23.55 \%$ & $35.36 \%$ & $50.19 \%$ \\
\hline
\end{tabular}

\subsection{Regression Model Results}

Table 3. Regression Results

\begin{tabular}{|c|c|c|c|}
\hline \multicolumn{4}{|c|}{$R O A_{i t}=\alpha+\beta_{1} S U S P_{i t}+\beta_{2} S_{I Z E_{i t}}+\beta_{3} A G E_{i t}+\beta_{4} C A R_{i t}+\beta_{5} L E V_{i t}+\varepsilon_{i t}$} \\
\hline Variable & Prediction & Coefficient & Probability \\
\hline SUSP & + & 0.073731 & 0.824 \\
\hline SIZE & + & 0.4448204 & $0.046^{* *}$ \\
\hline AGE & + & -0.1050311 & $0.000 * * *$ \\
\hline CAR & + & 5.638657 & $0.000 * * *$ \\
\hline LEV & - & -2.078582 & $0.000 * * *$ \\
\hline Cons. & & -18.46535 & 0.000 \\
\hline \multicolumn{2}{|c|}{ Adjusted $\mathrm{R}^{2}$} & \multicolumn{2}{|c|}{60.03} \\
\hline \multicolumn{2}{|c|}{ Prob $>\mathrm{chi}^{2}$} & \multicolumn{2}{|c|}{$0.0000^{* * *}$} \\
\hline
\end{tabular}

Before testing the hypothesis, researchers conducted treatment for normality and heteroskedasticity problems, we used General Least Square (GLS) and the results of the regression are presented in table 3. It can be seen that the value of Prob $>\mathrm{chi}^{2} 0.000$ is smaller than alpha 0.01. This means the independent variable has a simultaneous influence on its dependent variable. The value of Adjusted $\mathrm{R}^{2}$ is 60.03 which implies that both independent and control variables can explain the dependent variable by $60.03 \%$ while remaining is explained by other factors that are not included in this study.

In table 3 , SUSP probability is not significant which means that the sustainability practices and ROA have no relation and therefore the research hypothesis is rejected. This result is in line with studies by [18] [33] [40] [50] who could not find a relevant relation between CSR and financial performance. This is likely to happen because based on table 2 the rate of 
sustainability practices is very low in Islamic banking in Indonesia, which is only $23.33 \%$ on average. Further, the concern for sustainability that is manifested with sustainability reports is only carried out by large Islamic banks such as Bank Mandiri Syariah, BNI Syariah, BRI Syariah, and Bank Muamalat. In terms of regulations, disclosure of sustainability is still voluntary in Indonesia, whereas the regulations applied currently, Financial Services Authority Regulation No.51/POJK.03/2017 concerning the Application of Sustainable Finance for Financial Services Institutions, Issuers, and Public Companies, has not yet reflected the principles of Islamic banking that are dissimilar to conventional bank principles in general. This result may occur because according to [10] the effect of sustainability on performance will be stronger in the longterm period for example at $\mathrm{t}+1$.

Control variables that are positively associated with ROA are Bank Size and CAR with a significance level of 5\% and 1\%. Larger banks can use diversification as a tool for investment in organizational resources, and larger banks can use different technology and business models for their operations [1]. Banks with good capital are more efficient in follow up available business opportunities, more flexible and can cover unexpected losses generated during the crisis and as a result, they achieve a higher level of profitability [6]. The result of CAR is positively correlated with bank profitability also in line with previous studies by [6] [11] [27]. On the other hand, Bank Age and Leverage affect Islamic banks' financial performance in a negative direction at a significance of $1 \%$. Old banks may not use their assets to generate profits compared to young banks despite their asset limitations, with high efficiency can be used by younger banks to create profits and leverage negatively affect ROA in line with research by [36] [37].

\section{Conclusions}

This is the first study that measures sustainability practices (economic, environmental, and social) on the financial performance of Islamic banking in Indonesia based on GRI which transformed by Maqasid Al-Sharia theory. The result showed average practices of sharia banking sustainability during 2014 - 2018 were very low only $23.33 \%$, but these practices are proven to be increasing over the past 5 years at $50.19 \%$. Sustainability practices also have no relation to financial performance, which shows that these practices are not a priority in Islamic banking therefore regulators' role is required so this voluntary practice and reporting gain specific attention, which adjusted to the principles of Islamic banking. The weakness of this study is even though we use two scorers who are used to do sustainability content analysis based on GRI, the score of sustainability practices remains based on the judgment of scorer, so there is a subjective assessment. Furthermore, for further research, researchers can add other Islamic items to measure sustainability and test the relationship to financial performance in the longterm $(t+1)$ because the benefits of sustainability may not be realized in the short-term but can affect the long-term.

\section{References}

[1] Abedifar, P., Hasan, I., \& Tarazi, A. (2016). Finance-growth nexus and dual-banking systems: Relative importance of Islamic banks. Journal of Economic Behavior \& Organization, 132, 198-215.

[2] Adelabu, A., Z. Man, \& B. O. AbdulJubreel. (2011). Concept of profit maximization model in Islamic Commercial banking system and its weakness. Arabian Journal of Business and Management Review 1 (3):69-77. 
[3] Asutay, M. (2007). Conceptualisation of the second best solution in overcoming the social failure of Islamic banking and finance: Examining the overpowering of homoislamicus by homoeconomicus. IIUM Journal of Economics and Management, 15(2), 167-195.

[4] Asutay, M. (2012). Conceptualising and locating the social failure of Islamic finance: Aspirations of Islamic moral economy vs. the realities of Islamic finance. Journal of Asian and African Studies, 11(2), 93-113.

[5] Asutay, M. (2013). Islamic moral economy as the foundation of Islamic finance. In V. Cattelan (Ed.), Islamic Finance in Europe: Towards a Plural Financial System. Cheltenham: Edward Elgar Publishing.

[6] Athanasoglou, P. P., Brissimis, S. N., \& Delis, M. D. (2008). Bankspecific, industryspecific and macroeconomic determinants of bank profitability. Journal of International Financial Markets, Institutions and Money, 18,121- 136.

[7] Ben Naceur, S. and Omran, M. (2011), "The effects of bank regulations, competition, and financial reforms on banks' performance”, Emerging Markets Review, Vol. 12, pp. $1-20$.

[8] Bencivenga, V. R., \& Smith, B. D. (1991). Financial intermediation and endogenous growth. The Review of Economic Studies, 58(2), 195-209 https://doi.org/10.2307/2297964

[9] Bhatt, R. R., \& Bhattacharya, S. (2015b). Do Board Characteristics Impact Firm Performance? An Agency and Resource Dependency Theory Perspective. Asia-Pacific Journal of Management Research and Innovation. https://doi.org/10.1177/2319510X15602973

[10] Brogi, M., \& Lagasio, V. (2019). Environmental, social, and governance and company profitability: Are financial intermediaries different? Corporate Social Responsibility and Environmental Management, 26(3), 576-587. https://doi.org/10.1002/csr.1704

[11] Brundtland, G., 1987. Report of the World Commission on Environment and Development Our Common Future. Oxford University Press, United Nation.

[12] Demirguc-Kunt, A., \& Huizinga, H. (2000). Financial structure and bank profitability. Policy Research Working Paper Series 2430. The World Bank.

[13] Dietrich, A. and Wanzenried, G. (2011), "Determinants of bank profitability before and during the crisis: evidence from Switzerland", Journal of International Financial Markets, Institutions and Money, Vol. 21, pp.307-327.

[14] Dorasamy N. 2013. Corporate social responsibility and ethical banking for developing economies. Journal of Economics and Behavioral Studies 5(11): 777-785.

[15] Douglas, A., Doris, J., Johnson, B., 2004. Corporate social reporting in Irish financial institutions. The TQM Magazine 16 (6), 387-395.

[16] Farook, S., Kabir Hassan, M., Lanis, R., (2011). Determinants of corporate social responsibility disclosure: the case of Islamic banks. J. Islam. Account. Bus. Res. 2 (2), 114-141.https://doi.org/10.1108/17590811111170539.

[17] Fleege, E., Adrian, E., 2004. The implementation of corporate ethics: a comparative study between Motorola and Ericsson. J. Undergrad. Res. 7, 1-9.

[18] Freedman, M., \& Jaggi, B. (1982). An analysis of the informational content of pollution disclosures. Financial Review, 17(3), 142-152.

[19] Haniffa, R., Hudaib, M., 2004. Disclosure practices of Islamic financial institutions: an exploratory study. In: Conference Proceedings, 2004: The International Conference on Accounting, Commerce \& Finance: The Islamic Perspective, Brisbane, Australia.

[20] Hassan, A., Syafri Harahap, S. (2010). Exploring corporate social responsibility 
disclosure: the case of Islamic banks. Int. J. Islam. Middle East. Financ. Manag. 3 (3), 203-227.https://doi.org/10.1108/17538391011072417.

[21] Hurayra, M. A. (2015). Achievement of Maqasid-al-Shari'ah in Islamic Banking: An Evaluation of Islami Bank Bangladesh Limited. Global Journal of Computer Science and Technology: A Hardware \& Computation.

[22] ICD - Thomson Reuters Islamic Finance Development Report 2018: Building Momentum. https://ceif.iba.edu.pk/pdf/Reuters-Islamic-finance-developmentreport2018.pdf

[23] Imam, S., 2000. Corporate social performance reporting in Bangladesh. Managerial Auditing Journal 15 (3), 133- 141.

[24] Jan, A., Marimuthu, M., \& Hassan, R. (2019). Sustainable Business Practices and Firm's Financial Performance in Islamic Banking: Under the Moderating Role of Islamic Corporate Governance. Sustainability, 11(23), 6606.

[25] Jan, A., Marimuthu, M., \& Mat Isa, M. P. bin M. (2019). The nexus of sustainability practices and financial performance: From the perspective of Islamic banking. Journal of Cleaner Production, 228, 703-717. https://doi.org/10.1016/j.jclepro.2019.04.208

[26] Jan, A., Marimuthu, M., Shad, M. K., ur-Rehman, H., Zahid, M., \& Jan, A. A. (2019). Bankruptcy profile of the Islamic and conventional banks in Malaysia: a post-crisis period analysis. Economic Change and Restructuring, 52(1), 67-87. https://doi.org/10.1007/s10644-017-9220-7

[27] Kosmidou, K. The determinants of banks' profits in Greece during the period of EU financial integration. Manag. Financ. 2008, 34, 146-159.

[28] KPMG (2017), The road ahead: the KPMG survey of corporate responsibility reporting 2017. https://assets.kpmg/content/dam/kpmg/be/pdf/2017/kpmg-survey-of-corporateresponsibility-reporting- 2017.pdf.

[29] Kumar, Kishore \& Ajai Prakash. (2019). Examination of sustainability reporting practices in Indian banking sector. Asian Journal of Sustainability and Social Responsibility. 4:2. https://doi.org/10.1186/s41180-018-0022-2.

[30] Louzis, D.P., Vouldis, A.T. and Metaxas, V.L. (2012), "Macroeconomic and bankspecific determinants of non- performing loans in Greece: a comparative study of mortgage, business and consumer loan portfolios", Journal of Banking and Finance, Vol. 36 No. 4, pp. 1012-1027.

[31] Mallin, C., Farag, H., Ow-Yong, K., (2014). Corporate social responsibility and financial performance in Islamic banks. J. Econ. Behav. Organ. 103, S21-S38. https://doi. org/10.1016/j.jebo.2014.03.001.

[32] Mansour, W., K. Ben Jedidia, \& J. Majdoub. (2015). How ethical is Islamic banking in the light of the objectives of islamic law?. Journal of Religious Ethics 43 (1):51-77. doi:10.1111/jore.12086.

[33] McWilliams, A., \& Siegel, D. (2000). Corporate social responsibility and financial performance: Correlation or misspecification? Strategic Management Journal, 21, 603609.

[34] Meutia, I., Febrianti, D., (2017). Islamic social reporting in islamic banking: stakeholders theory perspective. In: SHS Web of Conferences 34. https://doi.org/ 10.1051/shsconf/20173412001. EDP Sciences. https://doi.org/10.1051/shsconf/ 20173412001

[35] Myers, T. A., \& E. Hassanzadeh. (2013). The interconnections between Islamic finance and sustainable finance. Manitoba,

Institute

Canada:

for
International

Sustainable 
Development.http://www.iisd.org/pdf/2013/interconnections_islamic_sustainable_financ e.pdf.

[36] Nawaz, T. (2017). Intellectual capital, financial crisis and performance of Islamic banks: Does Shariah governance matter? International Journal of Business and Society.

[37] Nawaz, T., \& Haniffa, R. (2017). Determinants of financial performance of Islamic banks: an intellectual capital perspective. Journal of Islamic Accounting and Business Research, 8(2), 130-142. https://doi.org/10.1108/JIABR-06-2016-0071

[38] Nobanee, Haitham, \& Nejla Ellili. (2015). Corporate Sustainability Disclosure in Annual Reports: Evidence from UAE Banks: Islamic versus Conventional. Renewable and Sustainable Energy Reviews.

[39] Olson, D. and Zoubi, T. (2011), "Efficiency and bank profitability in MENA countries", Emerging Markets Review, Vol. 12 No. 2, pp. 94-110.

[40] Patten, D. M. (1991). Exposure, legitimacy, and social disclosure. Journal of Accounting and Public Policy, 10, 297-308.

[41] Platonova, E. (2013). Corporate social responsibility from an Islamic moral economy perspective: A literature survey. Afro Eurasian Studies 2 (Issues 1\&2,Spring and Fall 2013): 272-97.

[42] Platonova, E., Asutay, M., Dixon, R., Mohammad, S., (2018). The impact of corporate social responsibility disclosure on financial performance: evidence from the GCC Islamic banking sector. J. Bus. Ethics 151 (2), 451-471. https://doi.org/10.1007/s10551016-3229-0.

[43] Polychronidou P, Ioannidou E, Kipouros A, Tsourgiannis L, Simet GF. 2014. Corporate Social Responsibility in Greek Banking Sector-An Empirical Research. Procedia Economics and Finance 9: 193-199.

[44] Raman SR. (2006). Corporate social reporting in India: a view from the top. Glob Bus Rev $7(2): 313-324$

[45] Siswantoro, D. (2017). Prinsip-Prinsip Islam Dalam Anggaran Sektor Publik APBN, APBD, dan APBDes yang Islami. Mujahid Press.

[46] Sobhani FA, Amran A, Zainuddin Y. Sustainability Disclosure in Annual Reports and Websites: A Study of the Banking Industry in Bangladesh. Journal of Cleaner Production 2012, 23: 75-85.

[47] Tan, Y. (2015), "The impacts of risk and competition on bank profitability in China", Journal of International Financial Markets, Institutions and Money, Vol. 40, pp. 85-110.

[48] Tran Y. 2014. CSR in the banking sector. A Literature review and new research directions. International Journal of Economics, Commerce and Management 2(11): 1-22.

[49] Trujillo-Ponce, A. (2013), "What determines the profitability of banks? Evidence from Spain”, Accounting \& Finance, Vol. 53 No. 2, pp. 561-586.

[50] Ullman, A. A. (1985). Data in search of a theory: A critical examination of the relationship among social performance, social disclosure, \& economic performance. Academy of Management Review, 10, 450-477.

[51] World Population Review. "Indonesia Population 2019" http://worldpopulationreview.com/. 